\title{
KETERLIBATAN ILUSTRASI DAN WARNA SEBAGAI STIMULUS VISUAL DALAM KONSEP 'INTERAKSI RUANG BELAJAR' PADA SEKOLAH DASAR KELAS 1-3 DI BALI
}

\author{
I Nyoman Larry Julianto1, Cokorda Alit Artawan², I Wayan Agus Eka Cahyadi ${ }^{3}$ \\ ${ }^{1,2,3}$ Prodi Desain Komunikasi Visual, Fakultas Seni Rupa dan Desain, Institut Seni Indonesia Denpasar \\ larry_smartdesign@ymail.com ${ }^{1}$
}

\begin{abstract}
Abstrak
Penelitian ini dilatarbelakangi adanya kebutuhan ruang belajar yang dapat berperan sebagai medium interaksi bagi anak usia Sekolah Dasar Kelas 1-3 di Bali. Adapun permasalahannya adalah kebutuhan sebuah konsep interaksi ruang belajar yang memberikan stimulasi visual dalam mendukung proses pembelajaran. Tujuan penelitian adalah menciptakan konsep interaksi ruang yang menghasilkan respon dari sebuah stimulus visual yang memiliki tahapan organisme (perhatian, pengertian, dan penerimaan) serta dapat mendukung capaian pembelajaran. Analisis kualitatif dengan metode prosedural dalam penelitian ini diawali dengan tahap pengumpulan data mengenai warna dan ilustrasi yang mampu memberikan efek rangsang visual bagi anak. Hasil analisis kemudian menjadi landasan berpikir dalam menciptakan sebuah konsep interaksi ruang belajar. Hasil penelitian menyatakan bahwa konsep interaksi ruang belajar harus memiliki nilai interaksi. Nilai tersebut dihasilkan melalui penerapan konsep interaksi ruang belajar yang bersifat tematik. Prinsip tematik mengacu pada upaya untuk meningkatkan motivasi serta menumbuhkan minat belajar anak dalam pencapaian tujuan pembelajarannya.
\end{abstract}

Kata Kunci: anak sekolah dasar, Bali, interaksi, ruang tematik

\begin{abstract}
This research was motivated by the need for a learning space that can act as an interaction medium for elementary school-aged children in grades 1-3 in Bali. The problem is the need for a concept of learning space interaction that provides visual stimulation in supporting the learning process. The research objective is to create a spatial interaction concept that produces a response from a visual stimulus that has an organism stage and can support learning outcomes. In this research, qualitative analysis with procedural methods began with collecting data about colors and illustrations that can provide visual stimulation effects for children. The results of the analysis became the basis of thinking in creating a concept of learning space interaction. The outcome of the research stated that the concept of learning space interaction must have interaction value. This value emerges through the application of the thematic learning space interaction concept. Thematic principles refer to efforts to increase motivation and foster children's interest in learning in achieving their learning goals.
\end{abstract}

Keywords: Bali, interaction, primary school children, thematic space 


\section{PENDAHULUAN}

Penelitian ini dilatarbelakangi oleh adanya suatu kebutuhan pada ruang belajar yang dapat berperan sebagai medium interaksi bagi anak usia Sekolah Dasar Kelas 1-3 di Bali. Interaksi yang dimaksudkan adalah melibatkan relasi antara guru dan siswa pada lingkungan belajarnya. Medium interaksi harus mampu memberikan suasana yang menyenangkan bagi anak serta mendukung tercapaianya tujuan pembelajaran (Rosarian \& Dirgantoro, 2020, p. 159). Proses pembelajaran merupakan sarana pengembangan potensi anak, sehingga dapat memahami tugas, peran serta tanggung jawabnya. Adapun keberhasilan proses pembelajaran dipengaruhi oleh beberapa faktor, salah satunya adalah lingkungan belajarnya. Memahami hal tersebut, maka dibutuhkan sebuah lingkungan belajar yang dalam proses interaksinya mampu menumbuhkan minat belajar anak. Minat belajar anak cenderung mampu ditumbuhkan dalam lingkungan belajar yang kondusif, menyenangkan, inovatif serta kreatif. Minat merupakan aspek terpenting dalam upaya meningkatkan motivasi siswa untuk dapat mencapai tujuan belajarnya. Minat dapat dipahami sebagai sebuah dorongan dalam diri seseorang yang mampu menimbulkan keinginan untuk menyukai sesuatu secara efektif. Upaya menumbuhkan minat cenderung dapat dilakukan dengan aktivitas kreatif pada ruang belajar yang bersifat menguntungkan, menyenangkan, menggembirakan serta dapat menghasilkan kepuasan tersendiri bagi anak. Melalui interaksi ruang belajar diharapkan setiap anak mampu mengembangkan proses konseptualisasi diri serta mengorganisir dirinya sendiri (Bali, 2017, p. 226).

Adapun permasalahan dalam penelitian ini adalah adanya sebuah kebutuhan mengenai konsep interaksi ruang belajar yang mampu memberikan stimulasi visual dalam mendukung proses pembelajaran. Interaktivitas anak pada ruang kelas sebagai lingkungan belajarnya, mampu membentuk konsep diri yang kreatif, dan cerdas secara mandiri. Peneliti mengamati bahwa adanya kecenderungan selama ini bahwa pihak pengelola Sekolah Dasar kurang memperhatikan fungsi dari dinding kelas sebagai sebuah medium interaksi, media ekspresi, dan literasi visual sebagai bagian dari proses edukasi. Sekolah Dasar merupakan tempat adanya kegiatan pendidikan berupa belajar mengajar untuk mengembangkan prestasi akademik dan non akademik setiap peserta didik. Kegiatan belajar merupakan sebuah proses yang dilakukan secara sengaja untuk menjadi sebuah pengalaman belajar, sehingga mampu menimbulkan adanya perubahan tingkah laku aktual dan potensial (Sudarti, 2019, p. 57).

Peran media pembelajaran sangat besar terhadap upaya interaksi edukatif antara pendidik dengan peserta didik. Mendukung hal tersebut, maka dalam proses pembelajaran cenderung membutuhkan stimulus untuk mempermudah pemahaman materi pelajaran. Stimulasi visual diharapkan mampu memberikan sebuah repson, sehingga dapat merubah tingkah laku anak menuju adaptif (Sudarti, 2019, p. 55). Adanya perubahan perilaku melalui interaksi stimulus dan respon, merupakan tolok ukur sudah terjadinya suatu tahapan belajar. Medium interaksi pada ruang belajar merupakan salah satu elemen yang harus berperan dalam membantu anak untuk memahami materi pelajarannya. Ruang belajar juga membutuhkan peran sebuah medium yang memiliki kemampuan untuk meningkatkan interaksi serta mampu mengembangkan kreativitas 
imaji visual anak. Keterlibatan ilustrasi dan warna pada ruang belajar anak yang berelasi dengan konten mata pelajarannya, merupakan salah satu strategi dalam proses komunikasi untuk menghasilkan stimulasi visual yang bermakna.

Upaya untuk mengekspresikan imaji anak dalam bentuk ilustrasi dan perpaduan warna merupakan sesuatu hal yang baik, sehingga perlu dikelola menjadi sebuah tindakan penyaluran energi yang bersifat positif. Adapun peranan ilustrasi dan warna sebagai elemen rangsang visual pada ruang belajar, merupakan sebuah media interaksi yang diharapkan mampu menjadi sebuah stimulus dalam upaya menumbuhkan minat belajar anak. Proses pembelajaran yang baik adalah pendidik mampu mempertimbangkan aspek - aspek perkembangan anak, aktivitas fisik yang akan dilakukan oleh anak serta kapasitas intelektualnya sehingga tujuan pembelajaran dapat tercapai secara optimal (Prima, 2019, p. 288). Peranan ilustrasi dan warna sebagai elemen rangsang visual akan meningkatkan motivasi belajar serta rasa keingintahuan siswa akan ilmu pengetahuan yang akan ataupun sedang dipelajari. Memahami permasalahan tersebut maka tujuan dari penelitian ini adalah mampu menciptakan sebuah konsep interaksi ruang yang menghasilkan respon dari sebuah stimulasi visual serta memiliki tahapan organisme (perhatian, pengertian dan penerimaan), sehingga siswa mampu mampu mengekspresikan dirinya dalam upaya mendukung tujuan dari capaian pembelajaran. Konsep tersebut diharapkan dapat berfungsi sebagai stimulus dalam upaya meningkatkan motivasi serta menumbuhkan minat belajar anak usia Sekolah Dasar kelas $1-3$ di Bali. Berikut akan diuraikan lebih lanjut mengenai metode yang digunakan dalam tahapan penelitian ini.

\section{METODE PENELITIAN}

Beberapa tahapan penelitian dilakukan untuk dapat menghasilkan sebuah 'konsep interaksi ruang' dalam keterlibatan ilustrasi dan warna sebagai elemen rangsang visual, sehingga dapat menjadi sebuah alternatif kebaruan dalam upaya memecahkan permasalahan di bidang pendidikan. Peneliti berpedoman pada model perancangan dari Christopher Jones (Atteng, Kumurur, \& Wuisang, 2016, p. 20), yakni metode prosedural yang bersifat kualitatif dan menekankan pada langkah penelitian sebagai upaya menghasilkan konsep sehingga mampu diwujudkan menjadi sebuah produk desain.

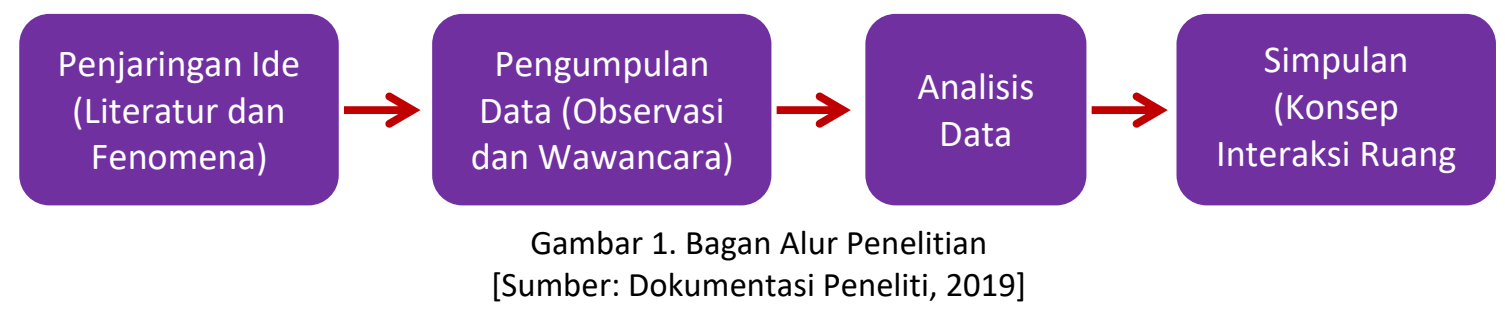

Adapun tahap pertama yang peneliti lakukan adalah menemukan sebuah ide atau gagasan untuk memecahkan permasalahan yang bersifat konkrit terkait peningkatan interaksi visual pada ruang belajar siswa. Peneliti memahami bahwa gagasan atau ide merupakan akar dari desain yang akan dirumuskan dengan aspek lain untuk dapat menghasilkan konsep interaksi ruang yang mampu menghasilkan respon dari stimulasi 
visual. Tahap kedua yang dilakukan peneliti adalah melakukan penggalian informasi dengan cara pengumpulan data melalui observasi lapangan mengenai warna yang menjadi kesukaan anak-anak usia Sekolah Dasar kelas 1 - 3 pada ruang belajarnya. Penggalian informasi atau data juga dilakukan untuk mendapatkan informasi mengenai pengejewantahan imaji visual anak-anak dalam wujud gambar, sehingga peneliti memberikan mereka kesempatan untuk berekspresi secara spontanitas dengan menggambar bertemakan 'bebas' pada media berupa kertas. Perolehan data atau informasi dari hasil observasi terhadap subyek penelitian tersebut, selanjutnya dianalisis untuk kemudian disimpulkan menjadi hasil riset yang bersifat holistik. Berbagai data dianalisa ekuivalensi dan kebenarannya melalui data empiris, sehingga data akan lebih mudah disintesis untuk menjadi sebuah konsep yang siap diujikan pada penelitian tahap selanjutnya. Tahapan wawancara secara langsung kepada guru dan siswa juga dilakukan untuk memahami validitas data terkait beberapa hal yang berhubungan dengan hasil temuan penelitian tahap sebelumnya. Hasil analisis merupakan sebuah simpulan yang akan diimplementasikan menjadi sebuah konsep interaksi ruang dalam keterlibatan ilustrasi dan warna sebagai elemen rangsang visual pada ruang belajar anak usia Sekolah Dasar kelas 1 - 3 di Bali.

Penelitian ini menggunakan analisis data kualitatif, sehingga mendukung pemahaman peneliti terhadap wacana komunikasi yang terjadi serta perkembangan budaya visual. Implementasi wacana tersebut dijewantahkan melalui 'konsep interaksi ruang' dalam strategi transisi imaji serta pengenalan konten mata pelajaran. Adapun hasil analisis merupakan sebuah upaya untuk dapat memahami nilai interaksi pada ruang belajar dalam keterlibatan ilustrasi dan warna sebagai elemen rangsang visual, sehingga diharapkan mampu meningkatkan motivasi serta menumbuhkan minat belajar siswa dalam mencapai tujuan belajarnya. Berikut diuraikan lebih lanjut terkait data hasil dan pembahasannya.

\section{HASIL DAN PEMBAHASAN}

Peningkatan mutu dalam proses pembelajaran dapat dilakukan dengan menciptakan kondisi belajar yang memungkinkan otak anak dapat berfungsi secara maksimal. Proses pembelajaran harus mampu menjadikan materi yang diterima, berhasil disimpan dalam memori anak sebagai peserta didik dalam jangka waktu yang lebih panjang. Perihal tersebut dapat dicapai dengan dukungan ruang belajar yang mampu menghubungkan informasi atau konten mata pelajaran dengan pengalaman yang telah dialami siswa. Keterlibatan ilustrasi dan warna sebagai elemen rangsang visual pada ruang belajar, merupakan sebuah upaya membentuk ruang belajar yang memiliki sebuah nilai interaksi. Berikut diuraikan lebih lanjut mengenai proses organisme dalam sebuah stimulasi visual, sehingga menghasilkan sebuah respon yang tentunya akan merubah tingkah laku anak.

\subsection{Proses Organisme dalam Stimulasi Visual}

Belajar merupakan serangkaian proses tertentu yang bertujuan untuk mengubah perilaku siswa melalui kegiatan interaksi yang menghasilkan respon dari suatu stimulus. Kegiatan belajar menjadi sebuah pemaknaan dari stimulasi visual yang terdapat pada 
ruang belajar, sehingga menghasilkan respon sebagai tolok ukur adanya sebuah peningkatan minat. Minat menjadi faktor utama dalam keberhasilan dari capaian tujuan pembelajaran. Ruang belajar yang mampu memberikan stimulus tentu akan menghasilkan respon sesuai dengan apa yang diharapkan. Dipahami bahwa perubahan melalui stimulasi visual dalam keterlibatan ilustrasi dan warna sebagai elemen rangsang visual akan mampu menimbulkan sebuah respon. Perihal tersebut terjadi akibat pemahaman bahwa stimulasi visual merupakan lingkungan belajar anak itu sendiri yang dapat dikatakan menjadi sebuah pengalaman belajar. Respon merupakan suatu akibat atau dampak yang dihasilkan terhadap sebuah stimultans. Respon yang baik dari sebuah stimulasi visual, cenderung akan menghasilkan proses pembelajaran yang menyenangkan bagi anak (learning is fun).

Menghasilkan sebuah proses pembelajaran yang efektif harus melalui tahap organisme dalam proses komunikasinya. Interaksi yang terjadi dalam ruang belajar yang mampu menghasilkan organisme, akan dapat meningkatkan motivasi serta menumbuhkan minat belajar anak. Menurut Eroglu (Hardianto, 2019, p. 68) bahwa organisme merupakan suatu kondisi perasaan dan kognitif anak yang mempengaruhi hubungan antara rangsangan dengan respon. Organisme merupakan suatu proses pengalaman belajar pada diri seseorang yang terdiri dari tahapan mempersepsikan, merasakan dan berpikir. Tahapan interaksi visual terjadi pada saat indera penglihatan seseorang mendapatkan sebuah rangsangan, kemudian seseorang tersebut akan mempersepsikan rangsang visual yang diterimanya dengan melibatkan perasaan serta pikirannya. Hasil rangsangan yang telah melalui tahapan organisme tersebut akan menentukan bagusnya respon yang dihasilkan.

Menurut Hawkins (Hardianto, 2019, pp. 68 - 69) bahwa tahapan mempersepsikan suatu stimulasi visual merupakan sebuah proses yang dimulai dari pemaparan rangsangan (exposure) terhadap konsumen, munculnya perhatian (attention) terhadap rangsangan tersebut, kemudian diakhiri dengan interpretasi (interpretation) yang dilakukan oleh seseorang terhadap suatu rangsangan visual. Rangsangan yang baik tentu akan menghasilkan respon yang sesuai harapan, sehingga dalam keterlibatan warna sebagai elemen rangsang visual, perlu dipahami warna apakah yang menjadi kesukaan anakanak usia Sekolah Dasar kelas 1 - 3 di Bali.
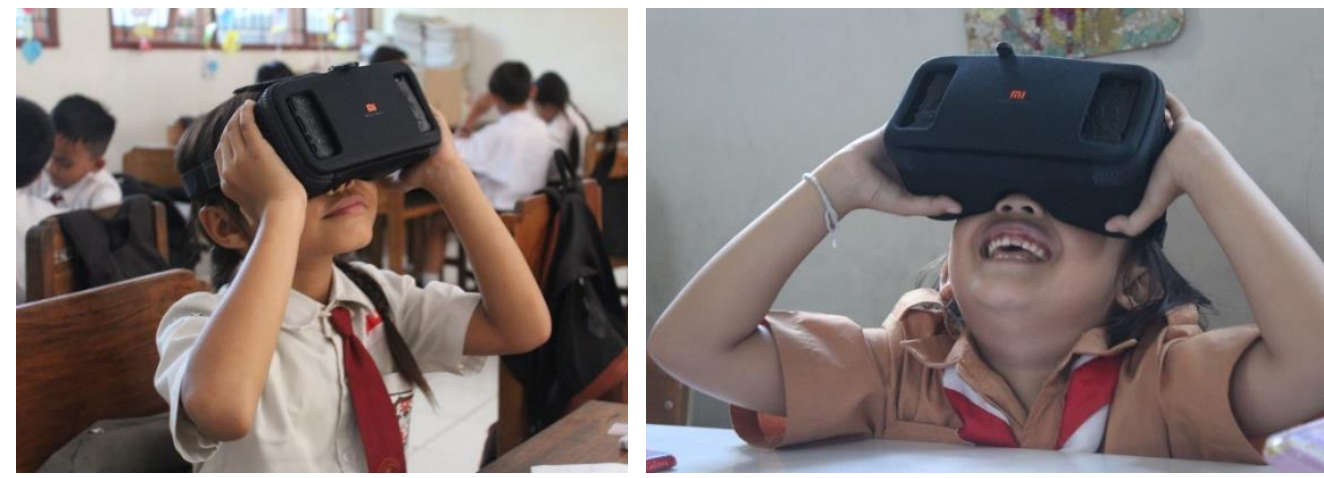

Gambar 2. Tahap Pengumpulan Data terkait Warna Kesukaan Anak Usia Sekolah Dasar Kelas 1-3 di Bali

[Sumber: Dokumentasi Peneliti, 2019] 
Memahami warna yang menjadi kesukaan anak-anak, merupakan sebuah upaya untuk menciptakan stimulasi visual dalam ruang belajar. Rangsangan yang diterima oleh indera penglihatan anak, selanjutnya akan dimaknai (decoding) menjadi sebuah arti yang mendalam. Proses pemaknaan terhadap warna dilakukan secara kognitif atau emosional. Hasil pengumpulan data diperoleh bahwa anak usia Sekolah Dasar kelas satu dan dua, memiliki kecenderungan tidak memiliki sebuah warna favorit yang bersifat pasti. Anak-anak dalam memilih warnanya, cenderung dipengaruhi oleh pilihan temannya. Begitu pula dengan anak kelas tiga, mereka mayoritas sudah memiliki warna favoritnya, namun bukan menjadi suatu fanatisme yang berlebihan. Artinya bahwa warna kesukaan mereka bukan merupakan keharusan warna yang digunakan seharihari. Kedua temuan data tersebut peneliti jadikan sebuah landasan berpikir dalam menciptakan konsep interaksi ruang belajar yang bersifat menarik dan dapat diterima oleh mayoritas anak dalam proses interaksinya.

Peneliti memahami bahwa proses memaknai suatu stimulasi visual, dipengaruhi oleh beberapa faktor seperti motivasi, persepsi, dan ingatan. Motivasi sangat berkaitan dengan kebutuhan anak yang dapat merubah serta mendorongnya untuk melakukan suatu respon atau tindakan tertentu. Persepsi berkaitan erat dengan kemampuan anak dalam memilih, mengurutkan, dan menginterpretasikan suatu informasi yang diperoleh dari lingkungan belajarnya, menjadi suatu gambaran yang memiliki makna tertentu. Persepsi terjadi bukan hanya dipengaruhi oleh wujud visual rangsangan saja, melainkan sangat tergantung juga dari kondisi dalam diri masing-masing anak (mood). Rangsangan visual yang diterima oleh anak akan memicu informasi yang mampu disimpan di dalam ingatannya. Ingatan sangat erat kaitannya dengan pengalaman belajar anak yang diperoleh pada masa lalu mereka. Memahami peran dari stimulasi visual, maka diperlukan ruang belajar anak yang mampu berelasi dengan mata pelajarannya. Perihal ini tentu akan berpengaruh terhadap kesadaran mental anak dalam memaknai sebuah rangsangan visual untuk menjadi sebuah tindakan perubahan sikap atau respon yang berelasi dengan konten dari mata pelajarannya. Stimulasi visual yang diciptakan dalam penelitian ini mengacu pada stimulus bersyarat untuk meningkatkan minat belajar anak di kelas.
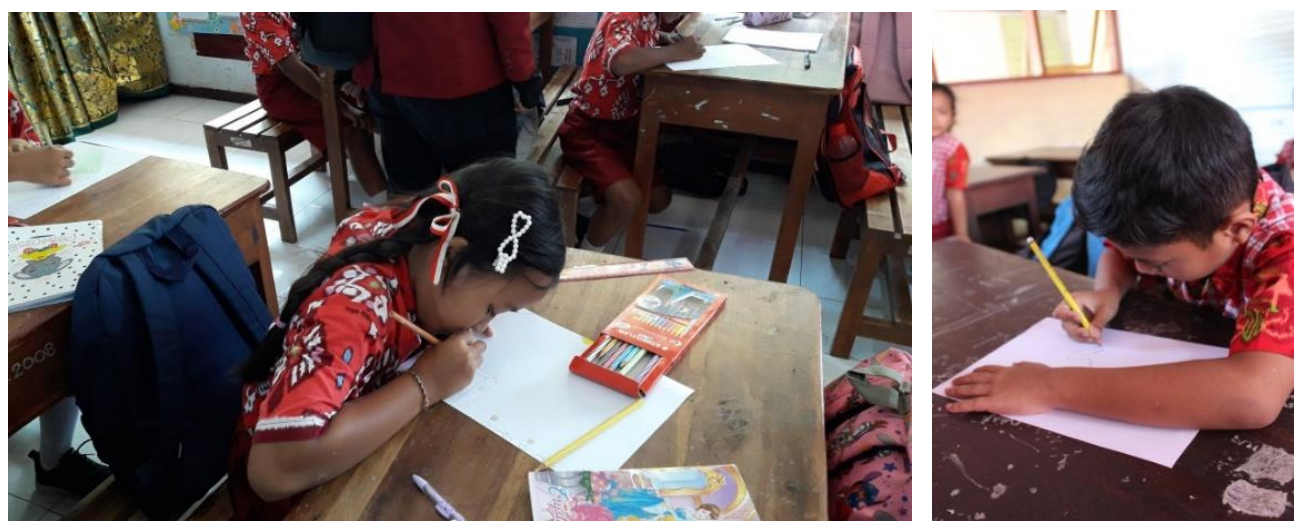

Gambar 3. Tahap Pengumpulan Data terkait Karakter llustrasi Kesukaan Anak Usia Sekolah Dasar Kelas 1-3 di Bali

[Sumber: Dokumentasi Peneliti, 2019] 
Respon merupakan hasil akhir dari proses pemaknaan secara kognitif yang terjadi dalam diri seseorang. Menghasilkan sebuah respon yang sesuai dengan tujuan capaian pembelajaran, maka perlu didukung oleh keterlibatan ilustrasi sebagai elemen rangsang visual dalam menghasilkan makna. Karakter ilustrasi apakah yang menjadi kesukaan anak-anak usia Sekolah Dasar kelas 1 - 3 di Bali, merupakah sebuah data penting yang perlu dipahami lebih mendalam, karena akan menjadi acuan landasan berpikir dalam menciptakan sebuah konsep interaksi ruang belajar. Hasil pengumpulan data melalui observasi langsung, dipahami bahwa terdapat kecenderungan anak usia Sekolah Dasar kelas 1 - 3 di Bali, lebih menyukai sebuah gambar yang mengacu pada kondisi alam atau bersifat natural.

Dua tahapan pengumpulan data di atas, menjadi landasan berpikir peneliti dalam menciptakan sebuah konsep interaksi ruang. Proses interaksi tentu menjadi sebuah pola komunikasi dalam ruang belajar anak, karena aspek komunikasi menjadi penting dalam dunia pendidikan sebagai upaya pencapaian tujuan pembelajaran. Tujuan dari adanya komunikasi dalam pendidikan bukan hanya bermanfaat untuk mentransfer keilmuan kepada anak didik (kognitif), namun juga berupaya untuk mampu merubah sikap dan perilaku anak atau aspek affective (Kurniawan, 2018, p. 62). Proses organisme menjadi aspek penting dalam upaya meningkatkan motivasi dan menumbuhkan minat belajar anak, sehingga sebuah stimulasi visual harus memenuhi tiga unsur yaitu perhatian, pengertian dan penerimaan. Penerapan stimulasi visual sebagai elemen interaksi dalam proses pembelajaran cenderung menghasilkan tingkat belajar yang lebih optimal, karena visual memiliki peran dalam membangun proses kognitif (Nurannisaa, 2017, p. 48).

Memahami perkembangan teknologi informasi dewasa ini tentu mengakibatkan anak cenderung tumbuh menjadi 'generasi visual', sehingga stimulasi visual akan menghasilkan feedback yang mengacu pada perubahan pola interaksinya (Julianto, 2019 , p. 30). Aspek visual mampu memberikan stimulasi terhadap berbagai macam kemampuan seorang anak dalam proses pencapaian tujuan belajarnya. Visual mengandung kedalaman makna karena perwujudannya yang tanpa kata tersebut cenderung sudah mampu menunjukkan sebuah arti yang mendalam. Tahap memaknai elemen rangsang visual berupa ilustrasi dan warna, merupakan proses belajar yang banyak dipengaruhi oleh faktor internal.

Faktor psikologis bersifat internal, sehingga mengacu pada beberapa aspek seperti minat, motivasi dan kecerdasan (Sudarti, 2019, pp. 63-64). Minat merupakan keinginan yang besar terhadap sesuatu serta dipengaruhi oleh pemusatan perhatian dan rasa keingintahuan. Motivasi merupakan suatu proses dalam diri seseorang yang aktif mendorong dan menjaga perilaku sesuai dengan tujuan. Terkait kecerdasan merupakan suatu kemampuan psikofisik dalam mereaksi rangsangan atau menyesuaikan diri dengan lingkungan melalui cara yang tepat. Elemen rangsang visual cenderung memiliki fungsi yang sangat penting dalam perkembangan proses berpikir anak. Proses berpikir sangat berkaitan erat dengan perkembangan aspek kognitif anak, karena menjadi salah satu aspek perkembangan anak yang berkaitan dengan pengertian (pengetahuan). 
Artinya bahwa semua proses psikologis berelasi erat dengan bagaimana seorang individu mampu mempelajari dan memikirkan lingkungan belajarnya.

\subsection{Nilai Interaksi dalam Konsep Interaksi Ruang Belajar}

Tahapan pengumpulan data memberikan sebuah wawasan yang baru bagi peneliti terkait penerapan warna pada ruang belajar anak. Peneliti mencermati bahwa beberapa ruang belajar anak di sekolah, memperlihatkan adanya suatu dominasi warna tertentu. Penerapan warna tersebut berdasarkan wawancara yang peneliti lakukan, diketahui bahwa bukan berdasarkan keinginan mayoritas anak-anak yang berada pada wilayah ruang belajar tersebut. Artinya penerapan warna tersebut merupakan hasil keputusan dari kesepakatan para pengelola sekolah dan komite orang tua. Penerapan warna tersebut ternyata memberikan sebuah dampak terhadap anak-anak. Adapun dampak yang kurang baik dihasilkan dari fenomena tersebut, yakni adanya kecenderungan anakanak mulai tidak menyukai warna yang mendominasi ruang belajar mereka. Perihal ini menjadi landasan berpikir sekaligus tantangan besar bagi peneliti dalam menciptakan sebuah konsep interaksi ruang belajar yang mampu memberikan nilia interaksi.

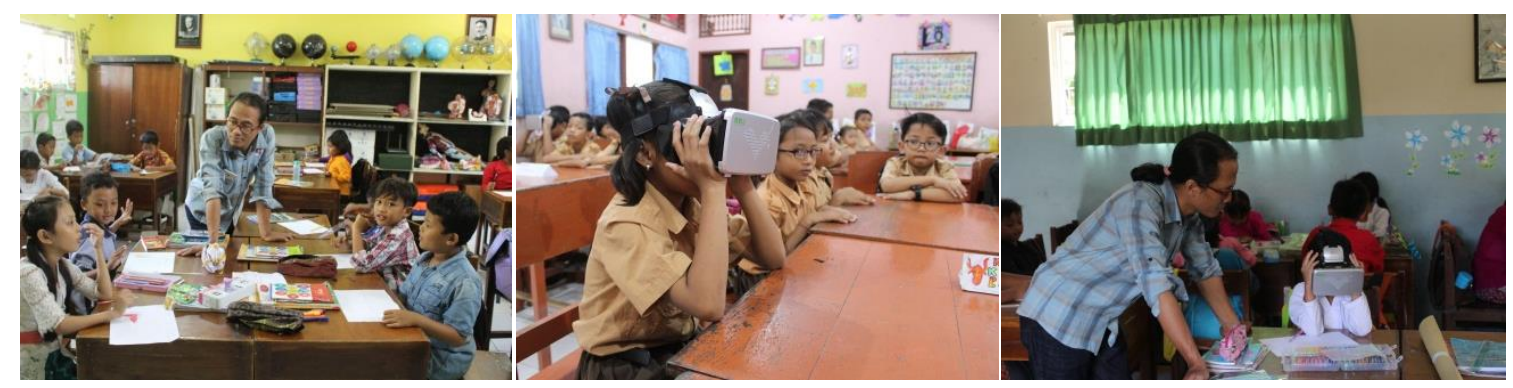

Gambar 4. Contoh Dominasi Warna pada Ruang Belajar Anak di Sekolah

[Sumber: Dokumentasi Peneliti, 2019]

Elemen rangsang visual cenderung memiliki fungsi yang sangat penting dalam perkembangan proses berpikir anak. Proses berpikir sangat berkaitan erat dengan perkembangan aspek kognitifnya, karena menjadi salah satu aspek perkembangan anak yang berkaitan dengan pengertian (pengetahuan). Artinya bahwa semua proses psikologis berelasi erat dengan bagaimana seorang individu mampu mempelajari dan memikirkan lingkungan belajarnya. Keterlibatan ilustrasi dan warna sebagai elemen rangsang visual dalam menciptakan sebuah konsep interaksi ruang belajar, maka dibutuhkan stimulasi visual bagi anak-anak yang bersifat tematik serta berelasi erat dengan konten dari mata pelajarannya. Memahami bahwa perubahan perilaku pada prinsipnya sama dengan proses belajar seseorang, maka kualitas rangsang visual (stimulus) yang berkomunikasi dengan organisme menjadi aspek penting dalam menghasilkan perhatian. Apabila stimulus telah mendapatkan perhatian dari organisme (diterima), maka seseorang dapat dikatakan mengerti atau mampu memaknai stimulasi tersebut, sehingga akan dilanjutkan kepada proses perubahan sikap (respon).

Prinsip tematik cenderung dapat menjadikan suasana lingkungan belajar anak menjadi sebuah stimulasi visual yang mampu menghasilkan respon sesuai dengan tujuan, karena dapat menjadikan ruang belajar lebih nyaman, mampu menumbuhkan nuansa 
keceriaan, keakraban, dinamis serta bersifat interaktif. Pemahaman peneliti sesuai dengan pendapat dari Everton \& Emmer (2015, p. 4) bahwa pengaturan ruang kelas yang baik adalah mampu memberikan siswa wilayah sirkulasi dan mobilitas yang tinggi serta bebas pada ruang belajarnya. Penataan ruang belajar merupakan sebuah tahapan dalam upaya menghilangkan berbagai hambatan yang dapat menghalangi terwujudnya interaksi dalam proses pembelajaran.

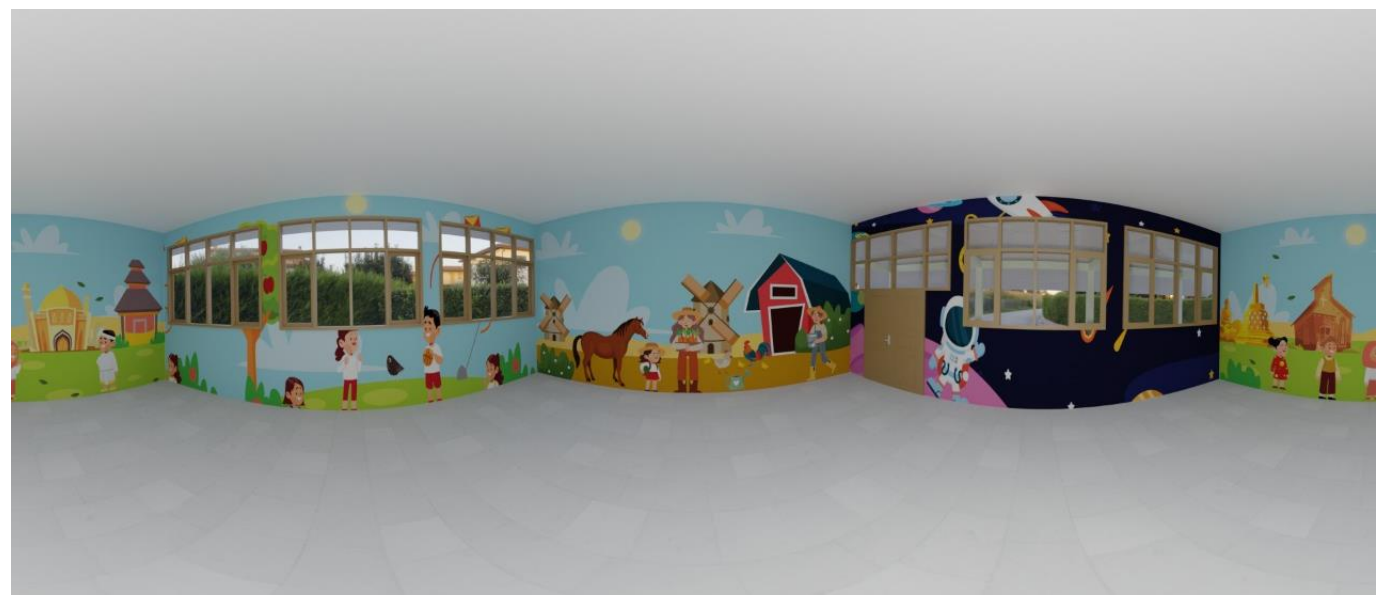

Gambar 5. Contoh Visualisasi Konsep Interaksi Ruang Belajar Tematik

(Sumber: Dokumentasi Peneliti, 2020)

Metode belajar yang terbaik, efektif dan mampu membuat anak lebih mudah menerima materi pelajaran di otaknya adalah belajar dengan proses yang menyenangkan. Belajar yang menyenangkan dapat menghindarkan seseorang dari 'keram otak' atau kondisi saat otak sudah tidak mampu menampung informasi tambahan untuk mengingat. Konsep interaksi ruang belajar tematik merupakan sebuah tawaran proses pembelajaran yang menyenangkan. Peran tematik dalam konsep yang dihasilkan dalam penelitian ini, mengacu pada upaya menjembatani proses transisi imaji anak-anak dari jenjang Taman Kanak-Kanak menuju Sekolah Dasar. Adapun strateginya adalah dengan menggunakan konten mata pelajaran tematik yang menjadi buku wajib dalam kurikulum 2013 pada jenjang Sekolah Dasar di Bali. Adapun beberapa tema mata pelajaran kelas 1 - 3 menitikberatkan pada prinsip hidup rukun, merawat hewan dan tumbuhan, alam semesta, persahabatan, permainan tradisional, kebersamaan dan keluarga. Beberapa tema tersebut diadaptasi kedalam bahasa visual untuk mendukung konsep interaksi ruang belajar tematik. Penekanan interaksi visual merupakan sebuah upaya proses komunikasi yang lebih bermakna antara siswa dan guru dalam mencapai tujuan belajarnya.

Nilai interaktivitas ilustrasi dan warna sebagai elemen rangsang visual yang bersifat tematik dipilih sebagai landasan berpikir dalam menciptakan konsep interaksi ruang belajar, dikarenakan pemahaman peneliti bahwa pengetahuan 'ketaksadaran' dalam memisualisasikan konsep tersebut, secara eksplisit mampu memberikan anak-anak sebuah pengalaman belajar atau informasi. Melalui keterlibatan ilustrasi dan warna yang bersifat tematik pada ruang belajar, menjadikan pengalaman belajar mereka terkonstruksi sebagai sebuah ingatan yang lebih mendalam (memorable experience). 
Proses stimulasi visual terkonstruksi menjadi sebuah ingatan yang mendalam, dikarenakan dalam proses interaksi dengan anak-anak tersebut terjadi dalam kondisi sadar, rileks, dan tanpa tekanan. Konsep interaksi ruang belajar tematik lebih mengutamakan aspek emosional anak melalui kebebasan berekspresi pada lingkungan belajarnya. Hal tersebut diperkuat dengan pendapat Evan Selinger yang menyatakan bahwa emosi merupakan pusat dari kemampuan manusia (Collins, 2010, p. 110).

Ruang belajar di sekolah harus mampu memberikan rasa nyaman bagi para penggunanya, yakni guru dan para siswa. Fenomena ruang belajar siswa Sekolah Dasar kelas 1 - 3 yang sampai masa sekarang cenderung belum memiliki sebuah "konsep interaksi ruang' dalam proses pembelajaran, sehingga berdasarkan analisis data di atas dapat dipahami bahwa sangat penting keterlibatan ilustrasi dan warna sebagai elemen rangsang visual pada ruang belajar. Wawancara peneliti lakukan terhadap guru untuk mengetahui strategi pengajaran dalam keterlibatan warna dan ilustrasi sebagai suatu sistem interaksi pada ruang belajar yang memiliki kriteria kreatif, efektif serta inovatif sebagai tolok ukur pencapaian tujuan pembelajan. Efektivitas kedua aspek tersebut tentu menjadi penelitian lanjutan, karena membutuhkan observasi dalam jangka waktu tertentu terhadap subyek penelitian yang diberikan sebuah perlakuan dari implementasi konsep yang peneliti berhasil ciptakan.

Visualisasi konsep interaksi ruang belajar tematik yang telah diciptakan, kemudian peneliti diskusikan kepada para guru wali kelas 1 - 3, untuk upaya penyempurnaan terhadap interaksi antara guru dan siswa melalui medium kreasi dalam upaya mempermudah proses pembelajaran. Hasil penelitian menyatakan bahwa penerapan konsep interaksi ruang belajar yang bersifat tematik dalam keterlibatan ilustrasi dan warna, harus berupaya untuk menjadikan konten mata pelajaran sebagai elemen rangsang visual. Elemen rangsang visual sebagai stimulus dalam upaya menghasilkan respon, maka harus bersifat tematik. Pemahaman tematik yang dimaksudkan adalah penerapan mural pada dinding ruang belajar harus sesuai dengan konten dari mata pelajaran selama satu tahun (dua semester). Perihal tematik inilah yang menjadi upaya untuk menciptakan problem solving, sehingga temuan penelitian ini merupakan suatu kebaruan dalam proses pembelajaran yang memberikan kenyamanan pada siswa. Tematik merupakan sebuah upaya untuk meningkatkan interaksi antara siswa dan ruang belajar serta gurunya. Interaksi visual sesuai jenjang pendidikan Sekolah Dasar kelas 1 3 di Bali harus mengacu pada keefektivannya sebagai sebuah konsep medium. Artinya para siswa dapat melakukan kreativitasnya pada sebuah medium dan medium tersebut sekaligus mampu memberikan stimulasi visual bagi siswa dalam tahapan untuk meningkatkan interaksi pada ruang belajarnya. Medium tersebut harus memiliki sebuah 'value' yang mampu melatih kebebasan siswa dalam berekspresi secara mandiri melalui penerapan ilustrasi dan warna pada medium kreativitas.

\section{KESIMPULAN}

Keterlibatan ilustrasi dan warna sebagai elemen rangsang visual pada ruang belajar harus memiliki nilai interaksi, yakni memberikan dampak stimulasi yang impresif bagi anak-anak. Nilai tersebut cenderung dihasilkan oleh penerapan konsep interaksi ruang 
belajar yang bersifat tematik. Bersifat tematik artinya wujud visual konsep interaksi ruang belajar berelasi erat dengan konten dari mata pelajaran anak usia Sekolah Dasar kelas $1-3$ di Bali. Prinsip tematik mengacu pada upaya untuk meningkatkan motivasi serta menumbuhkan minat belajar anak dalam upaya tercapainya tujuan pembelajaran.

Perwujudan konsep juga harus mampu memotivasi anak untuk berekspresi secara bebas namun tetap terjangkarkan. Motivasi akan menumbuhkan minat belajar siswa, sehingga mereka akan rela belajar tanpa adanya rasa keterpaksaan. Ruang belajar yang bersifat tematik cenderung kondusif dan kreatif, sehingga memberikan kesempatan mereka merasakan kenyamanan dengan lingkungan belajarnya. Interaksi visual memiliki peran yang kompleks, karena mampu menyinergikan gerak motorik, afektif dan kognitif secara baik. Konsep interaksi ruang belajar tematik menjadi teknik interaksi kebaruan bagi guru dan siswa, sehingga terciptanya kedekatan secara emosional dan sosial dalam proses pembelajaran di sekolah. Penerapan konsep interaksi ruang yang bersifat tematik diharapkan dapat meningkatkan fungsi otak kanan dan kiri siswa secara sinergis, sehingga dibutuhkan penelitian lanjutan terhadap keterlibatan elemen lainnya (medium) dalam proses anak-anak memahami materi pelajaran sekaligus dapat berekspresi secara bebas. Efektivitasnya dari konsep interaksi ruang belajar tematik yang menjadi temuan kebaruan dalam penelitian ini, juga dapat menjadi penelitian lanjutan karena membutuhkan observasi dalam jangka waktu tertentu, terhadap subyek penelitian yang diberikan sebuah perlakuan dari penerapan konsep tersebut.

\section{DAFTAR PUSTAKA}

Ajhuri, K. F. (2019). Psikologi Perkembangan. Yogyakarta: Penebar Media Pustaka.

Atteng, R. E., Kumurur, V. A., \& Wuisang, C. E. (2016). Produk Rancangan Urban Desain : Pendekatan Konsep "Marriage Old And New" Pada Perancangan Kawasan Wisata Religi Schwarz Di Langowan - Minahasa. Media Matrasain, 13(2), 15-29.

Bali, M. M. (2017). Model Interaksi Sosial dalam Mengelaborasi Keterampilan Sosial. Jurnal Pedagogik, 4(2), 211-227.

Cahyaningrum, E. S., Sudaryanti, \& Purwanto, N. A. (2017). Pengembangan Nilai - Nilai Karakter Anak Usia Dini Melalui Pembiasaan Dan Keteladanan. Pendidikan Anak, 6 (2), 203 - 213.

Collins, H. (2010). Tacit and Explicit Knowledge. Chicago: The University of Chicago Press.

Evertson, C. M., \& Emmer, E. T. (2015). Manajemen Kelas Untuk Guru Sekolah Dasar. Jakarta: Kencana Prenada Media Group.

Fibrianie, E., \& Cahyadi, D. (2017). Identification of Design and Development Needs for Preschool-aged Children's Educational Bags. Panggung, 27 (4), 344 - 352.

Gilang, L., Sihombing, R. M., \& Sari, N. (2017). Kesesuaian Konteks Dan Ilustrasi Pada Buku Bergambar Untuk Mendidik Karakter Anak Usia Dini. Pendidikan Karakter, $7(2), 158-169$.

Gilang, L., Sihombing, R. M., \& Sari, N. (2018). Kesesuaian Konteks Dan Ilustrasi Pada Buku Bergambar Untuk Mendidik Karakter Anak Usia Dini. Scholaria : Jurnal Pendidikan dan Kebudayaan, 8 (1), 41 - 50.

Hanisha, F., Djalari, Y. A., \& Hutama, K. (2018). Bahasa Visual, Gambar Anak dan Ilustrasi pada Buku Cergam Anak. Seni \& Reka Rancang, 1(1), 63 - 82. 
Hardianto, A. W. (2019). Analisis Stimulus-Organism-Response Model Pada "Dove Campaign For Real Beauty" 2004-2017. Jurnal Transaksi, 11(1), 65-79.

Julianto, I. N. (2019). Nilai Interaksi Visual dalam Perkembangan Medium Komunikasi pada Era Revolusi Industri 4.0. Senada. 2, pp. 26 -30. Denpasar: IDB Bali.

Kurniawan, D. (2018). Komunikasi Model Laswell dan Stimulus-Organism-Response dalam Mewujudkan Pembelajaran Menyenangkan. Jurnal Komunikasi Pendidikan, 2(1), 60-68.

Latifa, U. (2017). Aspek Perkembangan pada Anak Sekolah Dasar: Masalah dan Perkembangannya. Academica, 1(2), 185 - 195.

Massey, J. (2017). How to Illustrate a Children's Book. Retrieved Agustus 28, 2019, from Artist and Illustrator: https://www.artistsandillustrators.co.uk

Nurannisaa, S. (2017). Menghadapi Generasi Visual; Literasi Visual Untuk Menstimulasi Kemampuan Berpikir Dalam Proses Pembelajaran. Jurnal Pendidikan dan Pembelajaran Sekolah Dasar, 1(2a), 48-59.

Pamungkas, A. S. (2017). Pengembangan Bahan Ajar Berbasis Literasi Pada Materi Bilangan Bagi Mahasiswa Calon Guru SD. Pendidikan Sekolah Dasar, 3(2), 228 240.

Prima, E. (2019). Perbedaan Biologis dalam Pembelajaran dan Dampak dari Gerakan Fisik pada Otak Anak. Yinyang, 14(2), 271-290.

Rosarian, A. W., \& Dirgantoro, K. P. (2020). Upaya Guru Dalam Membangun Interaksi Siswa Melalui Metode Belajar Sambil Bermain. Journal of Holistic Mathematics Education, 3(2), 146-163.

Sudarti, D. O. (2019). Kajian Teori Behavioristik Stimulus Dan Respon Dalam Meningkatkan Minat Belajar Siswa. Jurnal Tarbawi, 16(2), 55-72.

Sunarto. (2017). Estetika Dalam Konteks Pendidikan Seni. Jurnal Refleksi Edukatika, 7(2), $102-110$.

Tafonao, T. (2018). Peranan Media Pembelajaran Dalam Meningkatkan Minat Belajar Mahasiswa. Komunikasi Pendidikan, 2(2), 103 - 114.

Woolfolk, A. (2017). Educational Psychology. Yogyakarta: Pustaka Pelajar. 